context which led Gambart to put together his "symbolic life" of St Francis, and of the somewhat broader backdrop of emblems and spirituality which provides a supporting intellectual framework for Gambart's work. Notwithstanding a few minor slips ("peak" for "pique") and minor errors (Albert Flamen, who engraved the plates for Gambart and for Augustin Chesneau's Orpheus Eucharisticus, was not the author of the Devises et emblemes d'amour moralisez), this is a very sound and eminently readable piece of scholarship.

In the end, then, the material by Elisabeth Stopp will primarily be useful to those who need the kind of crutch her translations and précis provide. Agnès Guiderdoni-Bruslé's essay, however, should interest even the specialist, and the facsimile of Gambart's book is a truly welcome addition to the list of modern emblem reprints.

DAVID GRAHAM, Concordia University, Montreal

\title{
Nabil Matar
}

\section{Britain and Barbary, 1589-1689}

Gainesville: University Press of Florida, 2006. Pp. xiii, 241

This is the third volume in Matar's trilogy dealing with Britain's relations with Islam in the sixteenth and seventeenth centuries. He covers the century from the first diplomatic embassies just after the collapse of the Spanish Armada through Britain's abandonment of its two-decade long occupation of Tangier. Through this period, Barbary was a powerful and threatening presence in English literature and politics. Piracy and slavery on both sides marked relations between the two, and Matar digs deep into the dynamics in a series of case studies. He probes the impact of Moorish ambassadors on English playwrights, and considers the results when thousands of Britons both male and female were enslaved by Barbary pirates; Matar offers two chapters that explore the effects on women in particular. The British reciprocated this piracy by integrating Moorish captives into their own slave trade. Their dawning realization that commerce paid greater dividends than conquest led them to abandon the Mediterranean and Tangier for more profitable American and Asian links, and that in turn led to the waning of the Moorish presence in British literature and politics. In the fading of both contact and threat, the powerful Moors of the Elizabethan imagination gave way to the decadent, obsequious, immoral, and exotic Moors of Enlightenment Orientalism; Moors had moved from being historical agents to "mere allegories." This raises the question, which Matar does 
not address here, of whether and how the image of the English shifted in Moorish imagination and politics. A study of this kind would round out our understanding of the Orientalist dynamic and make a fascinating fourth volume to complement this broadly researched and thoughtful trilogy.

NICHOLAS TERPSTRA, University of Toronto

\section{Janette Dillon}

\section{The Cambridge Introduction to Early English Theatre}

Cambridge: Cambridge University Press, 2006. Pp. xiv, 296

This accessible book takes its place within the Cambridge series mandated to introduce students to key topics and authors. It certainly succeeds in that regard and does so with a variety of implicit teaching approaches, offering an overview of English drama on stage and page from the earliest vernacular texts up to the closing of the theatres in 1642. Deemphasizing a perceived boundary between "medieval" and "early modern," this study covers both the continuities and divisions of English theatrical experience over some three centuries. Modernized spelling throughout certainly enhances continuity but also works effectively within an approach that is critical rather than chronological. Organized into five topical chapters, the work describes "Places of performance," "Actors and audiences," "Writers, controllers and the place of theatre," "Genre and tradition," and "Instruction and spectacle." The first two chapters feature case studies that focus attention and illustrate larger issues. In the first, the performance practices of Mankind, which are implicit in the text, are juxtaposed with the fuller evidence for the performance of The Masque of Blackness. In the second, brief attention to staging and costume in the N-Town The Death of Herod, is followed by a treatment of the later shock-and-awe self-consciousness of Edward Alleyn in the title role of Tamburlaine. Subsequent consideration of theatre and authority addresses the York Creed Play, Sidney's politicized playlet The Lady of May, and Middleton's later popular sensation A Game at Chess. Throughout, the specific influences of church and state, the Revels Office, professionalism, art, instruction, propaganda, and spectacle are all treated effectively.

An important feature of the book is the intervention of shaded and boxed quoted passages that relate to the argument and allow contemporary documents to speak for themselves in typographical isolation from the main text. Theseincluding legal depositions and ordnances, official and personal correspondence, contemporary pamphlet prose, and relevant passages from Shakespeare, Jonson, and 